\title{
The British Association: Some Early Documents
}

$\mathrm{M}^{\circ}$ OST appropriately at the time of its centenary, the British Association came into possession of a collection of letters and other documents retained, and in part mounted in a book, by John Phillips, its first secretary. These were saved from destruction and generously presented to the Association by Prof. W. J. Sollas, after they had been unearthed in the department of geology at Oxford, of which Phillips in later life became the head.

By far the most important letter historically is the first-that which Brewster wrote to Phillips in February 1831, proposing the establishment of a 'British Association of Men of Science', and a first meeting in York. The Association possessed until now only a copy of this letter. A large proportion of the letters are acceptances or refusals of invitations to that first meeting: one finds among them such signatures as Whewell, Buckland, Airy, J. F. W. Herschel, Scoresby, Rigaud, Baden Powell. There are several letters from Robison, who interested himself closely in the details of the arrangements. One observes anxiety as to whether the unsettled state of the country would make it expedient to postpone the inauguration of the Association until 1832: strange that both the birth and the centenary should have fallen in evil days. We have other letters from Brewster besides the first, one of which indicates that he forecast York, as a geographical centre, not only for the first meeting but also for the subsequent headquarters of the Association. We have the essential portion of the letter from Harvey of Plymouthunfortunately lacking the signature-from which Vernon Harcourt in his foundation speech borrowed, with acknowledgment, the comparison of the objects of the Association with Bacon's 'circuits of divers principal cities" in the "New Atlantis".

An outspoken letter from J. D. Forbes refers to one received by him from Whewell, who "in mentioning Dr. Brewster's attack upon Professors in their scientific character (which his best friends must allow to be unadvised and most unreasonable) ... adds that even if other circumstances permitted he should certainly not think of going to York, to rally under Dr. Brewster's banners. Now this is truly too absurd. That Dr. B. originated it $(s i c)$ there can be no doubt however $\mathrm{Mr}$. Murchison has endeavoured to confine its origin to London and the Geological Society (and I must say he treated his countrymen rather cavalierly on the occasion)-but to suppose that on that account the Doctor was to take any ostensible charge, so that even if he did a mere party feeling should keep men who ought to be above such things, from joining in a scheme intended for the general promotion of Science in Great Britain, is really vexatious. I believe I mentioned to you that Dr. B.'s nervousness in public is so great that even were he requested, he would be unable to act any conspicuous part at the Meeting. And it might nearly be considered the downfall of the Association, if the whole constellation of talent at
Trinity were thus to be withheld from fostering so infantile a project. I think you might devise some means for correcting the most erroneous views of the Cantabs. . . ." Forbes' pen was not prone to restraint, and there is a letter from Brewster to Phillips, quoting with pain some comments by Forbes, in writing to a third party, which injudiciously reflected upon Brewster's candidature for the chair of natural philosophy at Edinburgh, to which Forbes himself was afterwards appointed.

Perhaps the most attractive "human document" of the collection is the MS. report of a discussion on mineral veins, and other transactions, at the Cambridge meeting in 1833. The British Association has never been methodical in reporting its own discussions, and perhaps its reluctance, in earlier days at least, was not unwise, if this be a sample of a serious attempt at a report. Scientifically it is of little worth, save where John Phillips strikes out the reporter's version of his remarks and substitutes his own. The report starts, brightly, with the statement that "Mr. John Taylor read a paper on the state of our knowledge with regard to metallic veins, of which not much was audible in consequence of that low tone in which he read and the noise at the other end of the senate house". Sedgwick, as president, was in the chair, and proceeded to summarise the previous speaker's views " as far as he had understood him". Taylor, he said, had referred metallic veins to three causes" that they were injected from above, or forced up from below by convulsions of nature, or else were what was called contemporaneous, that is made by causes in nature always in operation ". Sedgwick remarked that for the results of this last proeess Whewell (" who had a great penchant for etymology and had larded our language with many words of his own invention ") had proposed the phrase "veins of segregation"; whereupon Whewell, apparently at considerable length, said nothing in particular upon a topic which was scarcely his own, in justification of his new term, which seemed to find acceptance.

Buckland had previously considered Taylor's three causes, rejecting the first, admitting the second as possible, preferring the third. "He had however some fourth case which I have forgotten," says the reporter naively, "I think it was that of sublimation" ; and a note is pencilled in Phillips" hand : "This was Dr. Buckland's favourite theory ; by this process he supposed nearly all cases of difficulty could be solved". Not so others: Murchison expressed the fear that Buckland's "brilliant harangue might have silenced some gentlemen present who, he knew, held opinions varying from those which that learned gentleman had expressed ". Sedgwick thought some of the distinguished foreigners present might have something to say, and that they were welcome to say it in French if they wished. A pleasant passage follows:

"Mr. Murchison. Mr. President, I am commissioned by the foreign gentlemen whom you have called upon to speak- - 
"President. No, no, not called upon: no one is called upon to speak-no one need speak unless they please.

"Mr. Murchison. Very well, Mr. President, then I am commissioned by the gentlemen whom you have not called upon to say that they are not at present prepared with arguments to refute Dr. Buckland's theories but probably may wish to do so at some future time."

Dr. Boase then stood forth, and began "in a very angry tone" by saying that he had "not been beaten down by Dr. Buckland's speech ", and Sedgwick and Murchison had both to assure him that they had never intended to suggest this (and indeed it was sufficiently obvious from what remains to us of the speaker's diatribe). Phillips then took up Whewell's theory of segregation, and by way of supporting it, remarked rather caustically that " he would venture to trespass so far on the attention of the meeting as to state the facts distinctly ". One faintly conceives Whewell's own sentiments on hearing this; but the meeting now appears to have concluded peacefully.

The proceedings at the general meeting on the following day seem, however, to have been even less harmonious. It opened, following a practice of the time, with reports of sectional transactions by appropriate representatives ; and so far all was well. Then Peacock read a paper on the analysis of algebra, amid a buzz of conversation which Sedgwick vainly attempted to check : at last. "the president requested that a constable should be sent up to stand by him " ; actually, " a servant" was procured. Sedgwick by this time may have been feeling the strain of his office : he " observed that Professor Henslow had some proposal which he wished to make to the meeting and he had better speak for himself, as he considered that Professor Henslow knew his own intentions better than he, for he could not understand them at all". Poor Professor Henslow had nothing less innocent to propose than a botanical excursion. " $\mathrm{He}$ believed the neighbourhood of Cambridge furnished little matter interesting to the geologist, or no doubt Professor Sedgwick would have been happy to-_ Professor Sedgwick: Talk of your own affairs if you please, Professor Henslow, and do not interfere with my business." The upshot was that the president, ex cathedra, said in effect that the botanists could do as they liked, but if the geologists wanted an excursion, he would rather be excused.

Certain further papers were given, including one by Rennie on hydraulics, "much too learned for common comprehension, and not well read". Finally, the president took the floor with a series of announcements, about "the ordinary", about a display of fireworks which " every member was invited to see and take with him a train of three ladies ", about a recondite jest of Whewell's concerning waterworks in place of the fireworks; and at last " after several times calling the assemblage back to hear different announcements which he had forgotten, the meeting broke up for that day".

Such, we must suppose, is the earliest attempt to provide brighter reports of the meetings. One suspects that the "Mudfog Papers" may have had some basis in reality.

\section{Physical Laboratories and Social Service*}

\section{By Sir Winmiam BragG, O.M., K.B.E., F.R.S.}

$\mathrm{I}^{\mathrm{N}}$ these days the services to be rendered by a physical laboratory become more definite than they were: not more stereotyped, because the possibilities and modes of their usefulness are increasing, but more clearly understood. With some curiosity I have read again an address which Lord Kelvin (then Sir William Thomson) gave at the opening of the physical and chemical laboratories at University College in Bangor in 1885. Thomson could then describe, as happenings of his own time, the beginnings of instruction in practical physics and chemistry and the construction of the necessary laboratories. Soon after he went to Glasgow, in 1846, he was in need of help with some electrical measurements and invited the aid of students, which was willingly given. Others heard that some of their fellows had got experimental work to do, and begged to be allowed to join in. This was the beginning of practical work for the students in his laboratories. Thomson recalled, with great zest, that three-quarters of his helpers were theological students, and that he had to explain to an amazed outsider that they seemed to be happy in their work and were getting on very well.

* From an address delivered at the opening of the new Physies Building of the University of Leeds on Feb. 18.

No. 3257 , VoL. 129]
At that time, of course, experimental science had already an accepted place, but there is a quaint evidence of a certain antagonism to it when he carefully explains that to measure the forms and properties of crystals is not to put them to an ignoble use.

At that time, also, the Cavendish Laboratory at Cambridge had got well under way; there were laboratories in the London colleges and elsewhere. But the number was small in comparison with that of to-day, when so many universities, colleges, schools, industrial firms, and other bodies have built and equipped laboratories, many of them magnificent in their equipments and their spaces. The nation itself has felt the need, and in 1899 founded the National Physical Laboratory at Teddington, where, also, a National Chemical Laboratory has now been working for the last few years. The research associations working in connexion with the Department of Scientific and Industrial Research have all their separate laboratories where physical and other research is carried on.

There has, in fact, been a great change since Thomson made his Bangor speech, in the general estimate of what may and ought to be expected from the physical laboratory. People are undoubtedly more interested in the growth of natural 